\title{
Pengaruh latihan range of motion (ROM) ankle terhadap pencegahan terjadinya neuropati dan angiopati pada klien diabetes melitus
}

\author{
Djunizar Djamaludin ${ }^{1}$, Setiawati², Rika Yulendasari ${ }^{3}$ \\ 1,2.3 Program Studi Ilmu Keperawatan Universitas Malahayati Bandar Lampung. Email: djunizar@malahayati.ac.id
}

\author{
Abstract \\ The effect of range motion (ROM) ankle exercise on prevention of neuropathy and angiopathy \\ in patient with diabetes mellitus
}

Background: Based on data from Basic Health Research (2013) conducted by the Indonesian Ministry of Health in a way to obtain the proportion of DM at the age of 15 years and over, confirmed / checked whether or not they suffer from DM or not.It was found that Lampung Province was ranked as the 8th largest DM person from 33 provinces throughout Indonesia, with DM patients with 38,923 lives and 5,560 people. One complication that needs attention is diabetes foot injury and it can cause amputation. The most common cause of diabetes foot injury is peripheral neuropathy which includes damage to sensory, autonomic and motor nerves.

Purpose: The purpose of this study was to determine the effect of Range of Motion (ROM) ankle exercise on prevention of neuropathy and angiopathy on diabetes patients.

Methods: A quasi experimental pre and post- test with control group study design was employed. The purposive sampling with 26 participants (13 respondents intervention group and 13 respondents control group) were recruited. The interventions groups performed ROM ankle exercise in their own respective training programs for 4 weeks, whereas no training was done in the control group. Both groups intervention and control, before and after the exercise program were measured with monofilament test for neuropathy and Venous Doppler for angiopathy. The data analysis was using t-test.

Results: In the intervention group there were a significant improvements after ROM ankle exercise on prevention of neuropathy with $p$ Value 0.000 and for angiopathy with $p$ Value 0.000 . There were significant different between intervention group and control group for neuropathy (p: .004) and angiopathy (p: .031).

Conclusion: To prevent neuropathy and angiopathy on diabetes patients a home exercise program with Range of Motion (ROM) ankle could be implemented

\section{Keywords: Range of Motion; Neuropathy; Angiopathy; Diabetes Mellitus}

Pendahuluan: Berdasarkan Riskesdas tahun 2013 oleh Kemenkes RI dengan melakukan wawan cara untuk mendapatkan proporsi DM pada usia 15 tahun keatas yaitu proporsi penduduk yang terdiagnosis menderita DM dan penduduk yang belum pernah didiagnosis menderita DM. Provinsi Lampung menduduki peringkat ke -8 penyandang DM terbesar dari 33 Provinsi diseluruh Indonesia, 38.923 jiwa dan 5.560 jiwa. Salah satu komplikasi yang harus mendapat perhatian yaitu luka kaki diabetes karena dapat mengakibarkan amputasi. Penyebab terbanyak dari luka kaki diabetes yaitu neuropati perifer yang meliputi kerusakan syaraf sensorik, otonom dan motorik.

Tujuan: Diketahui pengaruh Range Of Motion (ROM) Ankle terhadap pencegahan terjadinya Neuropati dan Angiopati pada pasien Diabetes Melitus.

Metode: Penelitian ini mengunakan desain quasi eksperimen pre post test dengan kelompok control dan intervensi..Sampel diambil dengan menggunakan tehnik Purposive Sampling dengan jumlah sampel yaitu 26 responden. Instrument penelitian ini menggunakan $10 \mathrm{gr}$ semmens weinstein monofilament untuk mendeteksi Neuropati dan Venous Doppler Ultrasound untuk mendeteksi angiopati.

Hasil: Menunjukkan adanya pengaruh latihan Range of Motion (ROM) Ankle terhadap pencegahan neuropati dengan $p$ Value 0.000 dan angiopati dengan $p$ Value 0.000 . Terdapat perbedaan bermakna antara kelompok intervensi dan control untuk neuropati (p: .004) dan angiopati ( $p:$.031).

Simpulan: Untuk mencegah terjadinya neuropati dan angiopati pada penderita DM untuk dapat melakukan latihan Range of Motion (ROM) Ankle dirumah

Kata Kunci: Range of Motion; Neuropati; Angiopati; Diabetes Mellitus 


\section{PENDAHULUAN}

Diabetes melitus (DM) merupakan suatu kelompok penyakit metabolik dengan karakteristik hiperglikemia yang terjadi karena kelainan sekresi insulin, kerja insulin, atau kedua duanya (Pengurus Besar Perkumpulan Endokrinologi Indonesia, 2015). Indonesia merupakan Negara dengan penyandang DM terbesar ke-5 diseluruh dunia, tercatat penyandang DM di Indonesia mencapai 9,1 juta jiwa pada tahun 2014 atau naik dua peringkat dari data tahun 2013 yang yang menempati peringkat ke-7 didunia dengan penyandang DM 7,6 juta jiwa (Atlas Diabetes, 2014). Berdasarkan hasil Riset Kesehatan Dasar (2013) yang dilakukan Kementrian Kesehatan RI Provinsi Lampung menduduki peringkat ke - 8 penyandang DM terbesar dari 33 Provinsi diseluruh Indonesia, dengan penderita DM 38.923 jiwa dan 5.560 jiwa (Departemen Kesehatan Republik Indonesia, 2013).

Penderita DM beresiko mengalami komplikasi salah satunya yaitu, luka pada kaki Pada luka kaki diabetes merupakan komplikasi yang ditakuti penderita DM karena dapat mengakibatkan terjadinya amputasi. Patofisiologi dari luka diabetes adalah komplek dan melibatkan multi faktor, diantaranya adalah: Neuropati sensorik, Penyakit arteri perifer (Angiopati), Depormitas kaki, dan Trauma eksternal. Neuropati perifer merupakan penyebab terbanyak dari luka kaki diabetes. Kerusakan syaraf sensorik mengakibatkan penderita tidak menyadari jika kakinya terkena benda tajam, sedangkan kerusakan syaraf otonom mengakibatkan produksi kelenjar keringat dan minyak menjadi terganggu, akibatnya kaki menjadi kering dan pecah pecah, yang lama lama dapat mengakibatkan bakteri dapat masuk kedalam kulit dan mengakibatkan infeksi, kerusakan syaraf motorik mengakibatkan perubahan bentuk kaki dan perubahan pada titik tekan kaki, sehingga lama lama akan terbentuk kalus atau kapalan yang tebal pada kaki. Kalus yang tebal apabila tidak ditipiskan lama lama akan mengalami inflamasi (peradangan) (Sari, 2015).

Pada kaki diabetes mengalami gangguan sirkulasi darah dan neuropati sehingga dianjurkan untuk melakukan senam kaki sesuai dengan kemampuan tubuh. Senam kaki adalah kegiatan atau latihan yang dilakukan oleh pasien diabetes melitus untuk mencegah terjadinya luka dan membantu melancarkan peredaran darah bagian kaki dan disimpulkan bahwa senam kaki memiliki berbagai manfaat bagi kaki diabetes, diantaranya adalah memperbaiki sirkulasi darah, Memperkuat otot - otot kecil, mencegah terjadinya kelainan bentuk kaki, meningkatkan kekuatan otot betis dan paha, serta membatasi keterbatasan gerak sendi. Senam kaki ini dapat diberikan pada seluruh penderita diabetes melitus dengan tipe 1 maupun tipe 2. Namun sebaiknya diberikan sejak pasien didiagnosa menderita diabetes melitus sebagai tindakan pencegahan dini namun tidak dianjurkan kepada Klien yang mengalami perubahan fungsi fisiologis seperti dipsnu atau nyeri dada, serta orang yang depresi, khawatir atau cemas (Ernawati, 2013).

Pencegahan dan penanganan Neuropati diabetikum serta perbaikan sirkulasi perifer (Angiopati) ditujukan untuk mencegah penderita DM mengalami ulkus diabetikum akan menurunkan resiko amputasi pada penderita DM, yang berarti menurunkan biaya karena hospitalisasi yang lama. Pengkajian keperawatan diabetikum menjadi salah satu hal yang penting dilakukan pada penderita DM hal ini menunjukan bahwa perawat (sebagai bagian dari tim multi disiplin) turut berperan dalam memonitoring berbagai faktor resiko penyebab ulkus diabetikum dan memberikan intervensi untuk mencegah agar faktor resiko tersebut tidak terjadi (Benbow, 2009 ). Pada kaki diabetes mengalami gangguan sirkulasi darah dan neuropati sehingga dianjurkan untuk melakukan senam kaki sesuai dengan kemampuan tubuh. Senam kaki adalah latihan yang dilakukan oleh pasien diabetes melitus untuk mencegah terjadinya luka dan membantu melancarkan peredaran darah bagian kaki (Ernawati, 2013).

Salah satu upaya pencegahan terjadinya neuropati dan angiopati pada penderita DM yaitu dengan latihan ROM (Range of Motion) pada ankle. Latihan ini merupakan salah satu tindakan keperawatan yang bertujuan untuk mengoptimalkan vaskularisasi pada daerah kaki diabetes dan Latar belakang penelitian tidak lebih dari 500 kata yang berisi latar belakang dan permasalahan yang akan diteliti, tujuan khusus, dan urgensi penelitian. Pada bagian ini perlu dijelaskan uraian tentang spesifikasi khusus terkait dengan skema. tindakan keperawatan yang bersifat mandiri yang bisa dilakukan oleh penderita DM dan keluarga (Wahyuni, 2016) 
Pengaruh latihan range of motion (ROM) ankle terhadap pencegahan terjadinya neuropati dan angiopati pada klien diabetes melitus

\section{METODE PENELITIAN}

Penelitian ini merupakan penelitian eksperimental dengan rancangan quasi experimental design dengan Pre - Post test Control Group design. Desain penelitian ini dengan membagi 2 kelompok yaitu kelompok control dan kelompok intervensi. Kelompok control dilakukan penilaian dengan menggunakan instrument $A B I$ (Ankle Brachial Index) dan sensasi proteksi tanpa dilakukan intervensi sebelum dan setelah penelitian. Sedangkan pada kelompok intervensi sebelum diberikan aplikasi ROM (Range of Motion) pada ankle dilakukan penilain $A B I$ (Ankle Brachial Index) dan Sensasi Proteksi kemudian diberikan intervensi ROM kemudian setelah itu di nilai dengan $\mathrm{ABI}$ (Ankle Brachial Index) dan Sensasi Proteksi.

Populasi dalam penelitian ini adalah semua pasien DM yang di rawat di RSUD Dr. H. Abdoel Moeloek Provinsi Lampung. Sampel diambil dengan menggunakan tehnik Purposive Sampling, dengan kriteria inklusi; Menderita $\mathrm{DM} \geq 5$ tahun; Usia penderita DM $\geq 50$ tahun; GDS $<250 \mathrm{mg} / \mathrm{dl}$ ( $\mathrm{N}: 80$ - $180 \mathrm{mg} / \mathrm{dll})$; Tidak menderita kelumpuhan ekstremitas bawah; Tidak terdapat inflamasi sendi ankle; tidak terdapat ulkus DM, selulitis, dan vaskulitis.

HASIL

Tabel 1. Analisis Selisih Nilai Sensasi Proteksi Dan Nilai ABI

\begin{tabular}{lcccc}
\hline Variabel & $\mathbf{n}$ & Mean $\mathbf{E}$ SD & $\mathbf{t}$ & $\mathbf{N}=\mathbf{2 6}$ \\
\hline $\begin{array}{l}\text { Sensasi proteksi kelompok } \\
\text { intervensi sebelum dan setelah } \\
\text { ROM ankle }\end{array}$ & 13 & $1,92 \pm 0,76$ & 9,12 & $0,00^{*}$ \\
$\begin{array}{l}\text { Sensasi proteksi kelompok kontrol } \\
\text { sebelum dan setelah ROM ankle }\end{array}$ & 13 & $0,00 \pm 0,81$ & 0,00 & 1,00 \\
$\begin{array}{l}\text { ABI kelompok intervensi sebelum } \\
\text { dan setelah ROM ankle }\end{array}$ & 13 & $0,11 \pm 0,06$ & 7,05 & $0,00^{*}$ \\
$\begin{array}{l}\text { ABI kelompok kontrol sebelum dan } \\
\text { setelah ROM ankle }\end{array}$ & 13 & $-0,01 \pm 0,03$ & $-1,15$ & 0,27 \\
\hline Paired samples test $a=0,05$ & & & &
\end{tabular}

Dari tabel diatas didapatkan data Analisis selisih nilai sensasi proteksi dan nilai $A B I$ kelompok intervensi dan kelompok kontrol sebelum dan setelah latihan ROM ankle. didapatkan rata - rata selisih nilai sensasi proteksi kelompok intervensi sebelum dan setelah penelitian adalah 1,92 $(S D=0,76)$ dengan hasil uji statistik $p=0,00$, dan disimpulkan bahwa adanya perbedaan bermakna pada nilai sensasi proteksi kelompok intervensi sebelum dan setelah penelitian $(p=0,00<a=0,05)$.

Tabel 2. Analisis Pengaruh latihan ROM ankle terhadap nilai sensasi proteksi dan nilai $A B I$

\begin{tabular}{|c|c|c|c|c|c|c|}
\hline & & & & & & $N=26$ \\
\hline Variabel & $n$ & Mean \pm SD & $t$ & df & Beda rerata $95 \% \mathrm{Cl}$ & $p$-value \\
\hline \multicolumn{7}{|l|}{ Sensasi proteksi } \\
\hline Kelompok intervensi & 13 & $4,92 \pm 2,36$ & $-3,23$ & 24 & $0,92-4,16$ & $0,004^{*}$ \\
\hline $\begin{array}{l}\text { Kelompok kontrol } \\
\mathrm{ABI}\end{array}$ & 13 & $7,46 \pm 1,56$ & & & & \\
\hline Kelompok intervensi & 13 & $1,00 \pm 0,09$ & $-2,30$ & 24 & $0,01-0,18$ & $0,031^{*}$ \\
\hline Kelompok kontrol & 13 & $0,91 \pm 0,12$ & & & & \\
\hline
\end{tabular}

Berdasarkan data diatas di dapatkan data analisis pengaruh pemberian latihan ROM ankle terhadap nilai sensasi proteksi dan nilai $\mathrm{ABI}$ pada kelompok intervensi dan kelompok kontrol.Pada

Djunizar Djamaludin', Setiawati ${ }^{2}$, Rika Yulendasari ${ }^{3}$

Program Studi llmu Keperawatan Universitas Malahayati Bandar Lampung. Email: djunizar@malahayati.ac.id 
Pengaruh latihan range of motion (ROM) ankle terhadap pencegahan terjadinya neuropati dan angiopati pada klien diabetes melitus

nilai sensasi proteksi didapatkan hasil uji statistik $p$ $=0,004$, dan hal ini dapat diyakini bahwa adanya perbedaan bermakna antara nilai sensasi proteksi kelompok intervensi dan kelompok kontrol setelah dilakukannya latihan ROM ankle $(p=0,004 a=$ $0,05)$. Sedangkan pada nilai $A B I$ didapatkan hasil uji statistik $p=0,031$ dan hal ini dapat diyakini bahwa adanya perbedaan bermakna antara nilai $\mathrm{ABI}$ kelompok intervensi dan kelompok kontrol setelah dilakukannya latihan ROM ankle $(p=$ $0,031 a=0,05)$.

\section{PEMBAHASAN}

\section{Pengaruh latihan ROM ankle terhadap pencegahan terjadinya neuropati.}

Latihan ROM ankle merupakan gerakan yang meliputi 2 gerakan yaitu dorsofleksi dan plantarfleksi yang mengakibatkan peningkatan kekuatan otot betis dan meningkatkan pompa otot betis sehingga memfasilitasi venous return yang berdampak positif dalam memfasilitasi difusi oksigen dan nutrisi (Rusandi, 2014).

Neuropati merupakan suatu komplikasi kronik dari DM dimana syaraf - syaraf telah megalami gangguan sehingga kaki penderita DM menjadi baal (tidak merasakan sensasi) dan tidak merasakan adanya tekanan, injuri/trauma, atau infeksi (Maryunani, 2013). Dalam pedoman penilaian sensasi proteksi adalah menggunakan Semmes Waisteins Monofilament $10 \mathrm{~g}$ pada 10 titik pemeriksaan, jika 4 dari 10 titik tersebut mengalami kegagalan merasakan sensasi maka menunjukkan penderita mengalami Neuropati (Widyawati, 2010).

Pada pemeriksaan awal penelitian ini di dapatkan nilai rata-rata sensasi proteksi responden kelompok intervensi adalah 5,54 titik sensasi atau dalam kategori mengalami neuropati, dimana keluhan utama yang dirasakan penderita diabetes melitus dengan neuropati adalah mati rasa pada kaki hal inilah yang menyebabkan penderita neuropati mengalami kehilangan sensori terhadap nyeri, vibrasi, tekanan dan panas (Widyawati, 2010). Sehingga dibutuhkan pemeriksaan sensasi dengan menggunakan Semmes Waisteins Monofilament $10 \mathrm{~g}$ pada 10 titik pemeriksaan.

Setelah dilakukan intervensi latihan ROM ankle selama 14 hari di dapatkan peningkatan nilai ratarata sensasi proteksi kelompok intervensi menjadi 7,46 titik sensasi atau dalam kategori normal, dengan selisih rata - rata 1,92 titik sensasi dan uji statistik menunjukan adanya perbedaan signifikan antara sensasi proteksi sebelum ROM ankle dan setelah dilakukan ROM ankle pada kelompok intervensi $(p=0,00<a=0,05)$.

Sedangkan pada kelompok kontrol didapatkan nilai rata-rata sensasi proteksi responden kelompok kontrol adalah 4,92 titik sensasi atau dalam katagori mengalami neuropati, dan setelah 14 hari kembali dilakukan pemeriksaan dan didapatkan hasil nilai rata-rata sensasi proteksi dalam nilai yang sama (4,92 titik sensasi), dengan selisih rata - rata nilai sensasi proteksi sebelum dan setelah penelitian 0,00 titik sensasi yang menandakan tidak ada perubahan yang terjadi pada nilai sensasi proteksi dan masih dalam kategori mengalami neuropati.

Pada akhir penelitian ini didapatkan nilai uji statistik pengaruh latihan ROM ankle terhadap nilai sensasi proteksi antara kelompok intervensi dan kelompok kontrol $p=0,004$ dengan $a=0,05$ dan $t$ hitung 3,23 serta $\mathrm{df}=24$, dimana dari dua porbabilitas antara variabel independen memiliki pengaruh terhadap variabel dependen atau tidak, dengan nilai $\alpha=0,05$ didapatkan nilai $t$ tabel sebesar 2,063. dan didapatkan data kesimpulan bahwa adanya pengaruh latihan ROM ankle terhadap peningkatan nilai sensasi proteksi atau dalam kata lain adanya pengaruh latihan ROM ankle terhadap pencegahan neuropati ditandai dengan $p=0,004<\alpha=0,05$, dan t hitung $=3,23\rangle$ $\mathrm{t}$ tabel $=2,063$ sehingga $\mathrm{H} 0$ gagal untuk diterima.

Penelitian tentang gerak sendi ekstremitas bawah terhadap nilai senssai banyak dilakukan peneliti - peneliti sebelumnya, diantaranya adalah, Widyawati (2010), tentang pengaruh ROM terhadap tanda neuropati dan didapatkan hasil penelitian $p$ value $=0,00$ pada pengukuran nilai sensasi proteksi awal dan akhir, sehingga disimpulkan adanya perbedaan yang bermakna. Hal yang sama juga didapatkan pada peneliti sebelumnya dengan menggunakan terapi senam kaki diabetes terhadap tingkat sensitifitas kaki, dan didapatkan hasil uji statistik $p$ value $=0,010$ sehingga berkesimpulan adanya pengaruh yang signifikan senam kaki terhadap peningkatan sensitifitas kaki diabetes (Sari, Haroen \& Nursiswati, 2016; Rusandi, 2014).

Pada penelitian diatas dan penelitian ini sendiri memang menerapkan terapi yang berbeda namun dengan melihat dari tujuan masing - masing terapi yang diterapkan memiliki kesamaan yaitu bertujuan 
Pengaruh latihan range of motion (ROM) ankle terhadap pencegahan terjadinya neuropati dan angiopati pada klien diabetes melitus

untuk memperlancar peredaran darah. Seperti penjelasan sebelumnya bahwa neuropati disebabkan oleh penumpukan sarbitol dan fluktosa dalam sel syaraf yang akan mengakibatkan edema syaraf dan berakibat terhambatnya mioinositol masuk kedalam sel syaraf, penurunan dan akumulasi sarbitol akan menimbulkan stress osmotik yang akan merusak mitokondria dan menstimulasi protein kinase $\mathrm{C}$ (PKC). Aktifitas PKC akan menekan fungsi Na-K-ATP-Ase, sehingga kadar $\mathrm{Na}$ intraseluler berlebihan, hal ini akan berakibat terhambatnya mioinositol masuk kedalam sel syaraf dan mengakibatkan transduksi sinyal pada syaraf terganggu (Ernawati, 2013).

ROM ankle merupakan salah satu terapi yang diprioritaskan karena memiliki fungsi yang berfokus pada kontraksi dan relaksasi otot betis melalui dua gerakan yaitu dorsofleksi dan plantarfleksi, kontraksi dan relaksasi otot betis merupakan calf pumping yang berperan penting mengembalikan venous return yang berdampak positif pada penurunan edema dan memfasilitasi difusi oksigen dan nutrisi (Taufiq, 2011; Wound Ostomy and Continence Nurses, 2003; Bryant \& Nix, 2015).

Kontraksi otot memiliki sifat seperti insulin (insulin like effect) selama olahraga sel otot lebih banyak menggunakan glukosa dan bahan bakar nutrien lain untuk menjalankan aktifitas kontraktil, laju transpor glukosa kedalam otot yang sedang berolahraga meningkat 10 kali walaupun tanpa insulin, dan permeabilitas membran terhadap glukosa meningkat pada otot yang berkontraksi, resistensi insulin berkurang , sebaliknya sensitivitas insulin meningkat, hal ini mengakibatkan tumpukan fluktosa pada sel berkurang dan mioinositol dapat masuk kedalam sel syaraf (Ernawati, 2013).

\section{Pengaruh latihan ROM ankle terhadap pencegahan terjadinya angiopati.}

Angiopati merupakan salah satu komplikasi kronik DM yang mengenai pembuluh darah, dan gangguan oklusif arteri pada ektremitas bawah mengakibatkan terjadinya gangren yang berakibat amputasi pada penderita DM (Ernawati, 2013). Pada awal pemeriksaan dalam penelitian ini didapatkan nilai rata-rata $A B I$ responden kelompok kontrol 0,89 atau dalam kategori rata-rata mengalami gangguan arteri sedang, dan setelah dilakukan latihan ROM ankle selama 14 hari didapatkan nilai rata-rata $A B I$ meningkatan menjadi
1,00 dengan selisih rata - rata 0,11 dan $p=0,00$ pada $a=0,05$ sehingga dapat disimpulkan adanya perbedaan secara signifikan antara nilai abi sebelum dilakukan latihan ROM ankle dan nilai $\mathrm{ABI}$ setelah dilakukan latihan ROM ankle atau dalam kategori nilai $A B I$ setelah latihan ROM ankle menjadi normal. Sedangkan pada responden kelompok kontrol pada awal pemeriksaan didapatkan nilai rata-rata $A B I 0,92$ atau dalam kategori normal, dan setelah 14 hari dilakukan kembali folow up didapatkan penurunan nilai ratarata $A B I(0,91)$ dengan selisih rata - rata $-0,01$ yang menunjukan adanya penurunan nilai $A B I$ akhir terhadap nilai $A B I$ awal walaupun masih dalam kategori nilai $\mathrm{ABI}$ normal.

Pada akhir penelitian ini didapatkan nilai uji statistik pengaruh latihan ROM ankle terhadap nilai $\mathrm{ABI}$ antara kelompok intervensi dan kelompok kontrol $p=0,031 \mathrm{t}$ hitung $=2,29$ dan $\mathrm{df}=24$ dimana dari dua porbabilitas antara variabel independen memiliki pengaruh terhadap variabel dependen atau tidak, dengan nilai $a=0,05$ didapatkan nilai $t$ tabel sebesar 2,063. dan dapat disimpulkan bahwa adanya pengaruh latihan ROM ankle terhadap peningkatan nilai $A B I$ atau dalam kata lain adanya pengaruh latihan ROM ankle terhadap pencegahan angiopati ditandai dengan $p$ $=0,031<a=0,05$, dan $\mathrm{t}$ hitung $=2,29>\mathrm{t}$ tabel $=$ 2,063 sehingga $\mathrm{HO}$ gagal untuk diterima.

Sejalan dengan penelitian terkait yang sejalan dengan hasil diatas, didapatkan pengaruh pemberian active lower ROM terhadap perubahan nilai $A B I$, dan didapatkan nilai rata - rata $A B I$ sebelum dan setelah intervensi sebesar 0,89 dan 0,90 dengan kesimpulan terdapat peningkatan 0,06 serta uji analisis $p$ value 0,002 sehingga dapat disimpulkan adanya pengaruh pemberian active lower ROM terhadap perubahan nilai $\mathrm{ABI}$ (Damayanti, 2012). Serta penelitian yang pernah dilakukan didapatkan selisih skor penyembuhan ulkus $0,03 p=0,005$, dari hasil penelitian ini membuktikan adanya perbaikan sirkulasi darah pada kaki penderitra diabetes sehingga terjadi proses penyembuhan ulkus DM (Taufiq, 2011).

Terjadinya kerusakan pada pembuluh darah penderita DM adalah karena imobilisasi yang berdampak pada peningkatan beban kerja jantung karena pada posisi supine aliran darah yang bersirkulasi kejantung meningkat, perpindahan cairan ini membuat peningkatan diastolik ventrikel kiri sehingga sistem kardiovaskuler cenderung 
Pengaruh latihan range of motion (ROM) ankle terhadap pencegahan terjadinya neuropati dan angiopati pada klien diabetes melitus

membentuk trombus, bekuan darah akibat statis vena yang berhubungan dengan berkurangnya kontraksi otot dikaki dan penekanan pada vena khususnya pada area politeal (Isdiaty, 2014). ROM ankle merupakan intervensi keperawatan yang secara aktif dan konsisten mengakibatkan kontraksi dan relaksasi pada otot - otot betis (calf pumping) yang berperan penting dalam pengembalian vena (venous return) (Maryunani, 2013).

\section{SIMPULAN}

Pada kelompok intervensi didapatkan ada perbedaan bermakna nilai sensasi proteksi antara pengukuran awal dan akhir penelitian pada kelompok intervensi $(p=0,00<a=0,05)$. Perbedaan bermakna nilai $A B I$ antara pengukuran awal dan akhir penelitian pada kelompok intervensi $(p=0,00<a=0,05)$. Pada kelompok kontrol didapatkan tidak ada perbedaan bermakna nilai sensasi proteksi antara pengukuran awal dan akhir penelitian $(p=1,00>a=0,05)$. Dan tidak ada perbedaan bermakna nilai $A B I$ antara pengukuran awal dan akhir penelitian ( $p=0,27>a=0,05)$. Ada pengaruh latihan ROM ankle terhadap pencegahan terjadinya neuropati dan angiopati, ditandai dengan perbedaan bermakna nilai Sensasi proteksi antara kelompok intervensi dan kelompok kontrol pada akhir penelitian $p=0,004<a=0,05$ dan $t$ hitung $=$ $3,23>t$ tabel $=2,063$, serta ada perbedaan yang bermakna pada nilai $\mathrm{ABI}$ antara kelompok intervensi dan kelompok kontrol pada akhir penelitian $p=0,031<a=0,05$ dan thitung $=2,29$ $>\mathrm{t}$ tabel $=2,063$.

\section{SARAN}

Menerapkan latihan ROM ankle pada perawatan pasien DM dengan kecendrungan gangguan neuropati dan angiopati sesuai kriteria (tanpa kontraindikasi) disamping 4 pilar penatalaksanaan DM. perlunya dilakukan penelitian lebih lanjut dengan jenis gerakan yang lain melibatkan tidak hanya ankle namun bagian lain pada ekstremitas bawah, mengingat vaskularisasi merupakan faktor terpenting pada masalah kaki diabetes. Perlu dilakukan penelitian terhadap faktor - faktor lain yang dapat mencegah terjadinya neuropati dan angiopati, tentunya dengan jumlah sampel yang lebih representatif.

\section{DAFTAR PUSTAKA}

Atlas Diabetes. (2015). International diabetes federation. IDF Diabetes Atlas, 7th edn. Brussels, Belgium: International Diabetes Federation.

Benbow, M. (2009). Fungating malignant wounds and their management. Journal of Community Nursing, 23(11).

Bryant, R., \& Nix, D. (2015). Acute and chronic wounds: current management concepts. Elsevier Health Sciences.

Damayanti, N. (2012). Buku pintar panduan bimbingan konseling. Yogyakarta: Araska.

DeLaune, S. C., \& Ladner, P. K. (2002). Fundamentals of Nursing: Standards \& Practice (Nursing Education).

Departemen Kesehatan Republik Indonesia. (2013). Riset kesehatan dasar tahun 2013. Jakarta: Badan Penelitian dan Pengembangan Departemen Kesehatan Republik Indonesia.

Ernawati, E., Setiawati, E. P., \& Kurniawan, T. (2015). Pengaruh Motivasi Internal dan Eksternal terhadap Diabetes Self Management di Wilayah Kecamatan Gombong Kabupaten Kebumen. Jurnal Sistem Kesehatan, 1(2)

Ernawati. (2013). Penatalaksanaan Keperawatan Diabetes Melitus Terpadu. Jakarta: Mitra Wacana Media.

Hidayah, A. (2012). Tingkat pengetahuan pasien diabetes mellitus tentang risiko terjadinya ulkus kaki diabetes di Poli klinik Penyakit Dalam Rumah Sakit Umum Pusat Haji Adam Malik medan.

Isdiany, N., \& Rosmana, D. (2014). Indeks Glikemik, Beban Glikemik, dan Asupan Energi Berperan dalam Pengendalian Kadar Glukosa Darah Penderita DM Tipe 2. Jurnal Riset Kesehatan, 7(1). 
Pengaruh latihan range of motion (ROM) ankle terhadap pencegahan terjadinya neuropati dan angiopati pada klien diabetes melitus

Lukita, Y. I., Widyati, N., \& Wantiyah, W. (2018). Pengaruh Range of Motion (ROM) Aktif Kaki terhadap Risiko terjadinya Ulkus Kaki Diabetik pada Pasien Diabetes Mellitus Tipe 2 di Desa Kaliwining Kabupaten Jember (The Effect of Active Leg Range of Motion on the Risk of Diabetik Foot Ulcer in Patient with. Pustaka Kesehatan, 6(2), 305-311.

Maryunani, A. (2013). Step By Step Perawatan Luka Diabetes Dengan Metode Perawatan Luka Modern. Bogor: In Media.

Nursiswati, N., Halfens, R. J., \& Lohrmann, C. (2017). Change in care dependency of stroke patients: A longitudinal and multicenter study. Asian nursing research, 11(2), 113-118.

Pengurus Besar Perkumpulan Endokrinologi Indonesia (2015). Konsensus pengelolaan dan pencegahan diabetes melitus tipe 2 di Indonesia. Jakarta: PB Perkeni.

Rangkuti, I. Y. (2011). Hubungan Antara Diabetes Melitus Tipe 2 Dengan Retinopati Diabetik Dikaji Dari HbA1c Sebagai Parameter Kontrol Gula Darah (Master's thesis).

Rosidah, A. (2016). Bimbingan kelompok melalui teknik problem solving untuk meningkatkan penyesuaian diri siswa terisolir. Jurnal Fokus Konseling, 2(2).

Rusandi, D. (2014). Pengaruh Senam Kaki Diabetes Terhadap Tingkat Sensitivitas Kaki Dan Kadar Glukosa Darah Pada Penderita Diabetes Melitus Di Kelurahan Banyuraden Gamping Sleman (Doctoral dissertation, STIKES Jenderal Achmad Yani Yogyakarta).
Sari, C. W. M., Haroen, H., \& Nursiswati, N. (2016). Pengaruh Program Edukasi Perawatan Kaki Berbasis Keluarga terhadap Perilaku Perawatan Kaki pada Pasien Diabetes Melitus Tipe 2. Jurnal Keperawatan Padjadjaran, 4(3).

Sari, Y. (2015). Perawatan luka diabetes. Yogyakarta: Graha IImu

Taufiq, I. (2011). Pengaruh latihan Range of Motion (ROM) ankle terhadap proses penyembuhan ulkus kaki diabetik di RSUD Dr. Hi. Abdul Moeloek dan RSUD Jendral A. Yani Propinsi Lampung (Doctoral dissertation, Tesis, Fakultas IImu Keperawatan, Program Magister IImu Keperawatan, Universitas Indonesia, Depok).

Wahyuni, A. (2016). Senam Kaki Diabetik Efektif Meningkatkan Ankle Brachial Index Pasien Diabetes Melitus Tipe 2. Jurnal Ipteks Terapan, 9(2), 19-27.

Widyawati, I. (2010). Pengaruh latihan rentang gerak sendi bawah secara aktif (active lower range of motion exercise) terhadap tanda dan gejala neuropati diabetikum pada penderita diabetes mellitus tipe II di persadia U IT RSU Dr. Soetomo Surabaya.

Wound Ostomy and Continence Nurses. (2003). Continence Nurses Society. Guideline for prevention and management of pressure ulcers, 11-17.

Yunus, B. (2015). Faktor-faktor yang Mempengaruhi Lama Penyembuhan Luka pada Pasien ULKUS Diabetikum di Rumah Perawatan ETN Centre Makassar (Doctoral dissertation, UIN Alauddin Makassar). 